\title{
PENGARUH MOTIVASI INTRINSIK, SIKAP, DAN NORMA SUBJEKTIF TERHADAP NIAT BERWIRAUSAHA MAHASISWA UNIVERSITAS SWASTA DI JAKARTA BARAT
}

\author{
Megi Elvando dan Ida Puspitowati \\ Program Studi Manajemen Universitas Tarumanagara \\ $\underline{\text { megiapan010499@gmail.com, idap@fe.untar.ac.id }}$
}

\begin{abstract}
The purpose of this study was to examine the effect of intrinsic motivation, attitudes, subjective norms on entrepreneurial intentions. The population of this study was 165 respondents spread across five private universities in West Jakarta. The non-probability sampling method was used by distributing online questionnaires using a google form which was then processed using smartPLS-SEM. The results of this study are intrinsic motivation,attitudes, and subjective norms affect to entrepreneurial intentions.
\end{abstract}

\section{Keywords : Intrinsic Motivation, Attitude, Subjective Norm, Entrepreneurship Intention}

\begin{abstract}
Abstrak : Tujuan dari penelitian ini adalah untuk menguji pengaruh motivasi intrinsik, sikap, norma subejktif terhadap niat berwirausaha. Populasi dari penelitian ini adalah 165 responden yang tersebar di lima Universitas Swasta di Jakarta Barat. Metode non-probability sampling digunakan dengan menyebarkan kuesioner secara online dengan menggunakan google form yang kemudian diolah menggunakansmartPLS-SEM. Hasil dari penelitian ini adalah motivasi intrinsik, sikap,dan norma subyektif berpengaruh terhadap niat berwirausaha.
\end{abstract}

Kata Kunci : Motivasi Intrinsik, Sikap, Norma Subjektif, Niat Berwirausaha,

\section{PENDAHULUAN}

Dewasa ini, praktek wirausaha menjadi topik yang ramai dibicarakan pada saat ini. Kewirausahaan sendiri telah menjadi pusat peran perkembangan dan berkembangnya ekonomi, hal ini dikarenakan munculnya tantangan globalisasi, perkembangan sosial, kompetisi, dan penurunan ekonomi (Soomro \& Shah, 2015). Kewirausahaan juga menjadi peluang yang sangat kuat bagi pertumbuhan ekonomi, yang akan membentuk jenis usaha baru, terbukanya lapangan pekerjaan yang baru, dan berkurangnya tingkat pengangguran di suatu daerah atau bahkan negara. Kewirausahaan dianggap sebagai salah satu solusi terhadap pengangguran yang terjadi Di Indonesia pelaku wirausaha masih sangat kecil dibanding dengan negara lainnya. Menurut data yang dikemukakan oleh Kementerian Perindustrian Republik Indonesia yang dikutip dari kemenperin.go.id (2018) memaparkan bahwa saat ini rasio wirausaha di dalam negeri masih pada angka yang relatif kecil, yaitu 3,1\% dari jumlah penduduk Indonesia, angka tersebut belum cukup untuk menjadikan Indonesia menjadi negara maju, walaupun angka tersebut sudah melampaui standar internasional, yaitu sebesar $2 \%$. Namun hal ini belum bisa menjadikan Indonesia unggul di sektor ekonomi dari pesaing, bahkan belum cukup untuk mengangkat dan meningkatkan sektor perekonomian Indonesia. Angka tersebut selayaknya menjadi acuan baik bagi pemerintah, maupun dari warga Indonesia sendiri untuk meningkatkan jiwa kewirausahaan, dan mulai mencoba hal baru. Menurut Hartarto (2018), "agar Indonesia menjadi negara maju, pemerintah harus terus memacu pertumbuhan wirausaha termasuk industri kecil dan menengah (IKM), sekaligus meningkatkan daya saingnya di era digital.”

Menurut Chatterjee dkk (2019) jumlah aktivitas kewirausahaan yang lebih besar secara 
proporsional dalam suatu masyarakat akan ada apabila ada tingkat kebutuhan yang cukup tinggi untuk pencapaian dalam suatu masyarakat. Tingkat kebutuhan yang tinggi dapat tercapai dari berbagai macam sumber, dari individu itu sendiri seperti menetapkan tujuan yang jelas, menggunakan keterampilan dan kemampuan untuk menjadi wirausaha yang sukses. Namun seseorang juga harus memiliki niat untuk melakukan sesuatu. Niat atau intensi merupakan dasar individu untuk berwirausaha dengan diimbangi pada keyakinan terhadap dirinya yang akan berdampak baik terciptanya wirausahawan baru (Hansfel \& Puspitowati, 2020). Untuk mencapai kesuksesan tersebut, motivasi dianggap sebagai hal yang penting bagi seseorang untuk memulai suatu usaha baru. Seperti yang dipaparkan pada penelitian yang dilakukan Anis dkk (2020) bahwa motivasi berpengaruh positif dan signifikan terhadap niat berwirausaha. Hal ini menunjukkan bahwa mahasiswa yang memiliki motivasi yang tinggi, memiliki rasa atau keinginan berwirausaha yang tinggi juga.

Selain memiliki motivasi, seorang individu juga harus memiliki sikap yang mumpuni untuk bisa menjadi seorang wirausawan. Menurut Indarti dan Rostiani (2008) sikap, perilaku dan juga pengetahuan para mahasiswa tentang kewirausahaan akan membentuk rasa atau keinginan untuk membuka usaha sendiri di masa yang akan datang. Hal ini didukung oleh penelitian yang dilakukan oleh Aniss dkk (2020) bahwa sikap berpengaruh positif dan signifikan terhadap niat berwirausaha. Sikap dianggap sebagai pilar seorang individu dalam menentukkan tujuan dan langkah selanjutnya. Faktor lain dapat mempengaruhi seseorang memulai usaha baru, selain dari yang dipaparkan di atas, terdapat faktor pendukung, yaitu norma subjektif, lingkungan yang ada di sekitar kita sangat berpengaruh kepada perilaku dan kehidupan kita sehari-hari.

Berdasarkan uraian latar belakang tersebut, maka peneliti tertarik melakukan penelitian terkait pengaruh motivasi intrinsic, sikap, dan norma subjektif terhadap niat berwirausaha mahasiswa Universitas Swasta di Jakarta Barat.

\section{LANDASAN TEORI}

\section{Motivasi Intrinsik}

Deci dan Ryan (2010) mendefinisikan motivasi intrinsik sebagai salah satu jenis motivasi yang didasarkan pada minat alami orang dalam melakukan berbagai aktivitas yang memberikan tantangan baru. Motivasi dijelaskan sebagai salah satu tipe dari motivasi yang berdasarkan dari ketertarikan alamiah seorang individu pada bermacam-macam aktivitas yang baru dan juga menantang. Selain itu Lin (2007) mengemukakan definisi dari motivasi intrinsik, yaitu, motivasi intrinsik menunjukkan kesenangan dan kepuasan yang melekat yang berasal dari aktivitas tertentu. Menurut Deci dan Ryan (2010) Motivasi intrinsik didefinisikan sebagai keinginan untuk melakukan suatu aktivitas untuk kepuasan yang melekat dan dapat memisahkan konsekuensi yang ada. Definisi ini hampir sama dengan yang dikemukakan oleh Lin (2007) bahwa motivasi intrinsik memunculkan kegiatan dari rasa kepuasan itu sendiri

\section{Sikap}

Sikap sendiri tidak dapat dipisahkan dari perilaku manusia, karena melalui sikap suatuperilaku dapat dimunculkan dan akan memberikan respon atau tanggapan. Chaplin (1975 dalam Anwar, 2009) mendefinisikan sikap atau attitude sebagai suatu kecenderungan atau presdiposisi yang berlangsung secara terus menerus yang relatif stabil dilakukan untuk bertingkah laku atau untuk bereaksi akan sesuatu dengan cara tertentu. Schwarz dan Bohner (2001) mendefinisikan sikap adalah suatu kondisi yang dibangun di tempat, terlepas dari apakah mereka dinilai secara langsung atau tidak langsung merajuk kepada tindakan yang implisit. Hal ini menunjukkan bahwa attitudes atau sikap dapat terbentuk melalui lingkungan atau tempat dimana seseorang 
tumbuh dan berkembang, dapat secara langsung (dari diri sendiri) ataupun secara tidak langsung (melalui perantara atau pengaruh dari orang lain). Sedangkan Menurut Eagly dan Chaiken (1993) Sikap adalah kecenderungan psikologis yang diekspresikan dengan mengevaluasi entitas tertentu berdasarkan penilaian suka atau tidak suka.

\section{Norma Subjektif}

Norma subjektif merupakan keyakinan yang ada pada setiap individu terhadap lingkungan yang ada di sekitarnya serta motivasi individu untuk mengikuti norma tersebut (Feldman, 1995). Norma subjektif dianggap sebagai acuan bagaimana manusia berperilaku, karena norma subjektif dianggap sebagai tekanan sosial yang ada di masyarakat luas. Norma Subjektif (subjective norm) merupakan persepsi individu terhadap individu lain disekitarnya, seperti teman, panutan atau keluarga dalam membuat keputusan (Hartono \& Puspitowati, 2019).

\section{Kaitan antara Motivasi Intrinsik dengan Niat berwirausaha}

Listyawati (2020) menyatakan bahwa terdapat hubungan yang signifikan positif antara motivasi dan juga niat berwirausaha. Pada penelitian tersebut diperoleh hasil bahwa motivasi yang ada pada diri seorang individu (dalam hal ini motivasi intrinsik) merupakan faktor kuat pembentuk niat seseorang dalam menjalankan kewirausahaan.

\section{H1 : Motivasi Intrinsik berpengaruh dengan niat berwirausaha.}

\section{Kaitan antara Sikap terhadap Niat Berwirausaha}

Penelitian yang dilakukan oleh Rochayati, Mahardika, dan Arum (2013) menyatakan bahwa sikap berpengaruh signifikan positif terhadap niat berwirausaha, sikap dalam hal ini mencakup rasa percaya diri, pantang menyerah, tepat waktu, dan juga senang bersosialisasi.

\section{H2 : Sikap berpengaruh terhadap niat berwirausaha.}

\section{Kaitan antara Norma subjektif dengan Niat Berwirausaha}

Santi, Hamzah, \& Rahmawati (2017) menyatakan norma subjektif berpengaruh positif signifikan terhadap niat berwirausaha. Dalam penelitian ini menunjukkan bahwa lingkungan membentuk persepsi dan keyakinan seseorang dalam memulai berwirausaha (dalam hal ini norma subjektif).

\section{H3 : Norma Subjektif berpengaruh terhadap niat berwirausaha}

\section{METODE PENELITIAN}

Jenis penelitian yang digunakan pada penelitian ini adalah penelitian kuantitatif deskriptif. Penelitian ini menggunakan metode cross-sectional yaitu proses pengumpulan data dari sampel suatu populasi yang hanya dilakukan sekali pada waktu tertentu saja. Pada penelitian ini data yang diambil dikonversi menjadi angka dengan menggunakan skala 1 sampai dengan 5 dengan pernyataan sangat tidak setuju sampai dengan sangat setuju. Pada penelitian ini terdapat variabel independen yaitu motivasi intrinsik, sikap, dan norma subjektif. Variabel dependen pada penelitian ini yaitu niat berwirausaha. Adapun jenis teknik pemilihan sampel yang digunakan adalah non probability sampling yaitu teknik pemilihan sampel yang tidak memberikan peluang atau kesempatan yang sama bagi populasi yang dijadikan sampel (Sugiyono, 2008), untuk teknik pengambilan sampel, peneliti menggunakan teknik pengambilan sampel purposive sampling. Menurut Sugiyono (2008) purposive sampling merupakan teknik pengambilan sampel dengan menentukkan pertimbangan tertentu. Dalam penelitian ini sampel yang ditentukan yaitu mahasiswa dan mahasiswi Fakultas Ekonomi dan Bisnis atau Fakultas Ekonomi pada Universitas 
swasta di Jakarta Barat yaitu: Universitas Tarumanagara, Universitas Trisakti, Universitas Bina Nusantara, Universitas Mercu Buana, dan Universitas Kristen Krida Wacana. Menurut Roscoe (1975) ukuran sampel yang baik dalam mengambil sampel penelitian berkisar antara 30 sampai dengan 500 responden. Pengambilan sampel pada penelitian ini, menggunakan sampel sebanyak 165 sampel. Analisis pada penelitian ini digunakan PLS-SEM. Menurut Hair et al. (2011) PLSSEM sangat baik dan cocok untuk digunakan dalam mengolah data dengan sampel yang kecil dan jumlah yang sedikit.

\section{HASIL DAN PEMBAHASAN}

Berdasarkan data yang diperoleh dari 165 responden, serta mengacu bahwa suatu indokator dianggap valid apabila memiliki hasil uji validitas $>0.50$ atau dengan melihat nilai loading factor, yaitu harus $>0.50$. Berikut hasil pengujian Validitas, diperoleh hasil bahwa 19 indikator dinyatakan Valid, dimana Sembilan belas indikator tersebut $>0.50$.

Tabel 1

Outer Loading

\begin{tabular}{|c|c|c|c|c|c|}
\hline & $\begin{array}{l}\text { Motivasi } \\
\text { Intrinsik }\end{array}$ & Sikap & $\begin{array}{l}\text { Norma } \\
\text { Subjektif }\end{array}$ & $\begin{array}{l}\text { Niat } \\
\text { Berwirausaha }\end{array}$ & Keterangan \\
\hline M1 & 0.886 & & & & Valid \\
\hline M2 & 0.624 & & & & Valid \\
\hline M3 & 0.817 & & & & Valid \\
\hline M4 & 0.782 & & & & Valid \\
\hline SP1 & & 0.744 & & & Valid \\
\hline SP2 & & 0.688 & & & Valid \\
\hline SP3 & & 0.743 & & & Valid \\
\hline SP4 & & 0.807 & & & Valid \\
\hline SP5 & & 0.743 & & & Valid \\
\hline SP6 & & 0.779 & & & Valid \\
\hline NS1 & & & 0.827 & & Valid \\
\hline NS2 & & & 0.890 & & Valid \\
\hline NS3 & & & 0.752 & & Valid \\
\hline NS4 & & & 0.877 & & Valid \\
\hline NW1 & & & & 0.788 & Valid \\
\hline NW2 & & & & 0.728 & Valid \\
\hline NW3 & & & & 0.659 & Valid \\
\hline NW4 & & & & 0.798 & Valid \\
\hline
\end{tabular}


*Sumber: Hasil olah data SmartPLS versi 3.0

Pada uji reliabilitas suatu indikator dapat dikatakan reliable jika Cronbach's Alpha $>0.60$ dan nilai Composite Reliability >0.70. Berikut merupakan tabel Cronbach's Alpha dan Composite Reliability dimana nilai Cronbach's Alpha pada masing-masing variabel memiliki nilai $>0.60$, dan Composite Reliability pada masing-masing variabel memiliki nilai $>0,70$ sehingga dapat dikatakan reliable dan dapat diandalkan.

Tabel 2

Cronbach's Alpha dan Composite Realibility

\begin{tabular}{|l|l|l|}
\hline Variabel & Cronbach's Alpha & Composite Reliability \\
\hline Motivasi Intrinsik & 0.783 & 0.861 \\
\hline Sikap & 0.846 & 0.886 \\
\hline Norma Subjektif & 0.858 & 0.904 \\
\hline Niat Berwirausaha & 0.731 & 0.833 \\
\hline
\end{tabular}

*Sumber: Hasil olah data SmartPLS versi 3.0

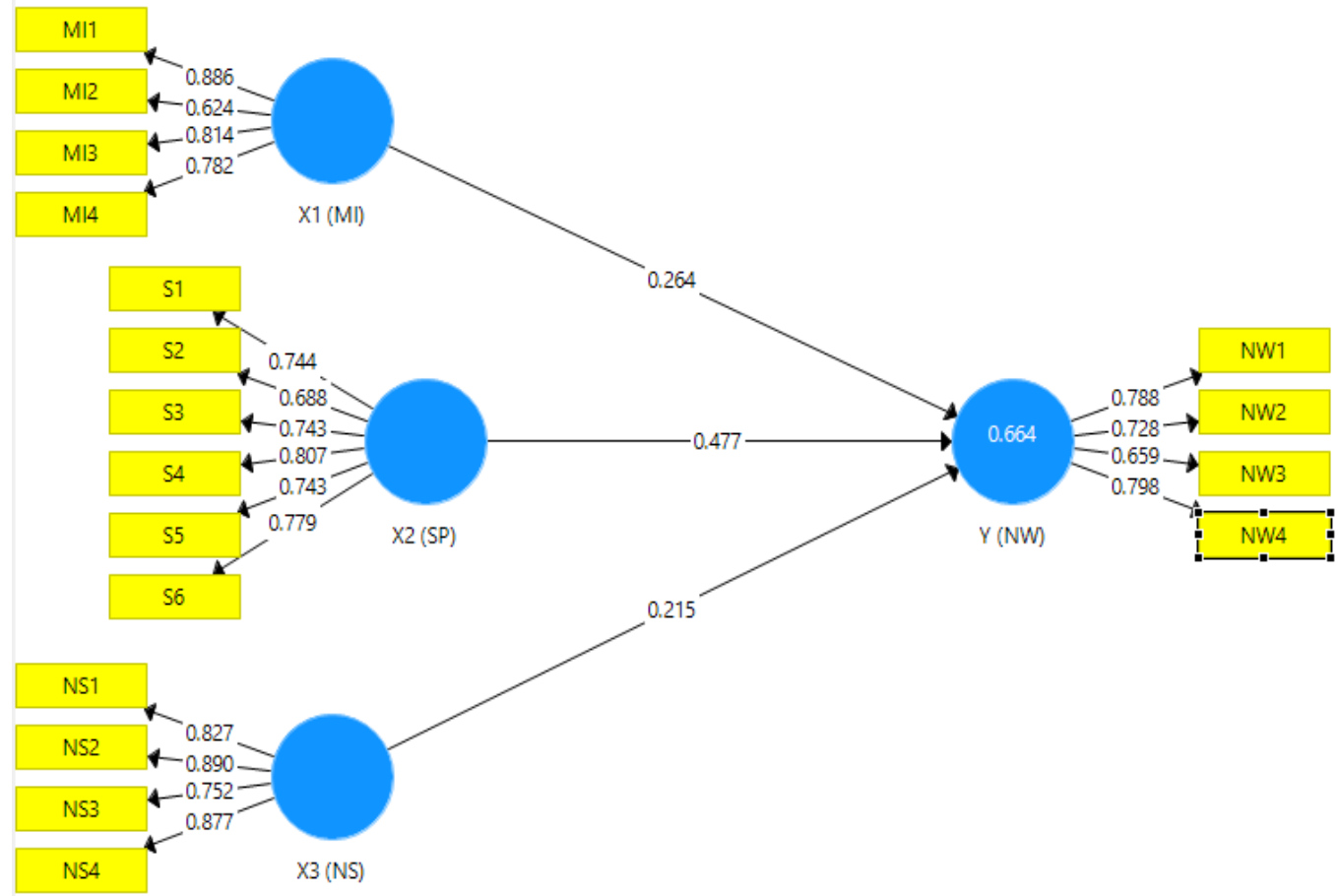

Gambar 1. Hasil Bootsraping

Berdasarkan data responden sebanyak 165, terdiri dari 75 responden pria dan 90 responden wanita. Berdasarkan kelompok usia, mayoritas responden berada pada rentang usia 20-21 tahun, 
yaitu sebanyak 96 responden. Pendidikan yang ditempuh saat ini, mayoritas responden berada pada semester akhir yaitu semester 7-8 dengan 132 responden, kemudian mayoritas Universitas responden, berasal dari Universitas Tarumanagara dengan 96 responden.

Pada penelitian ini digunakan analisis Smart PLS Ver.3.Model teoritis yang telah digambarkan pada diagram jalur sebelumnya akan dilakukan analisis berdasarkan data yang telah diperoleh. Berdasarkan nilai t- statistik dari suatu hubungan kausalitas dari hasil pengolahan data sebagai berikut.

Tabel 3

Path Coefficients (Mean, STDEV, T-Values)

\begin{tabular}{lccccc}
\hline & Original & Sample & STDEV & T & P \\
& Sampel & Mean & & Statistik & Value \\
\hline Motivasi Intrinsik -> Niat Berwirausaha & 0,264 & 0,275 & 0,118 & 2,240 & 0,026 \\
Sikap -> Niat Berwirausaha & 0,477 & 0,474 & 0,110 & 4,331 & 0,000 \\
Norma Subjektif -> Niat Berwirausaha & 0,215 & 0,206 & 0,077 & 2,811 & 0,000
\end{tabular}

Sumber : SmartPLS versi3.0

Berdasarkan uji hipotesis yang dilakukan, hasil dalam penelitian ini menunjukkan bahwa Motivasi Intrinsik berpengaruh terhadap Niat Berwirausaha Mahasiswa Universitas Swasta di Jakarta Barat, dengan nilai p-value sebesar 0,017 yang artinya lebih kecil dari <0.05, sehingga nilai dinyatakkan diterima atau signifikan terhadap variabel Niat Berwirausaha, dan nilai $t$-statistic sebesar 2.387, yang artinya signifikan, karena lebih dari 1.96. Maka dapat disimpulkan bahwa H1 diterima, yang berarti Motivasi Intrinsik berpengaruh signifikan terhadap Niat Berwirausaha, Hasil penelitian ini sejalan dengan penelitian yang dilakukan Listyawati (2020) yang menyatakan bahwa terdapat hubungan yang signifikan positif antara motivasi dan juga niat berwirausaha, pada penelitian tersebut diperoleh hasil bahwa motivasi yang ada pada diri seorang individu (dalam hal ini motivasi intrinsik). Selain itu penelitian yang dilakukan Munawar dan Supriyatna (2018) juga menyatakan hal yang sama yaitu bahwa motivasi memiliki pengaruh terhadap niat berwirausaha. Hal ini dapat diartikan bahwa Motivasi Intrinsik berpengaruh terhadap Niat Berwirausaha Mahasiswa Universitas Swasta di Jakarta Barat.

Variabel sikap memiliki nilai $p$-value sebesar 0.000 di mana nilai $p$-value $<0.05$ menunjukkan bahwa variabel sikap diterima atau signifikan terhadap variabel niat berwirausaha, dengan nilai $t$-stattistic sebesar 4.469 di mana jika nilai $t$-statistic $>1.96$ maka dinyatakan signifikan, dengan demikian H2 diterima, yang berarti, Sikap berpengaruh signifikan terhadap Niat berwirausaha. Hasil penelitian ini sejalan dengan penelitian yang dilakukan Rochayati, Kusumawardani, dan Sari (2013) menyatakan bahwa sikap berpengaruh signifikan positif terhadap niat berwirausaha, sikap dalam hal ini mencakup rasa percaya diri, pantang menyerah, tepat waktu, dan juga senang bersosialisai. Penelitian yang dilakukan Munawar dan Supriyatna (2018) juga menyatakan hal yang sama, yaitu sikap berpengaruh terhadap niat berwirausaha. Hal ini dapat diartikan bahwa Sikap berpengaruh terhadap Niat Berwirausaha Mahasiswa Universitas Swasta di Jakarta Barat

Selanjutnya variabel norma subjektif memiliki nilai $p$-value sebesar 0.003 dimana nilai $p$ value $<0.05$ menunjukkan bahwa variabel norma subjektif diterima dan nilai $t$-stattistic sebesar 2.894 di mana jika nilai $t$-statistic $>1.96$ dinyatakan signifikan, dengan demikian $\mathrm{H} 3$ diterima. Hasil penelitian ini sejalan dengan penelitian yang dilakukan Rahmawati dan Mawardi (2017) yang menyatakan hal yang sama, yaitu norma subjektif berpengaruh positif signifikan terhadap niat berwirausaha Norma Subjektif berpengaruh terhadap Niat 
berwirausaha Mahasiswa Universitas Swasta di Jakarta Barat.

\section{KESIMPULAN}

Berdasarkan hasil penelitian mengenai pengaruh motivasi intrinsik, sikap, dan norma subjektif terhadap niat berwirausaha mahasiswa universitas swasta di jakarta barat dapat disimpulkan bahwa Motivasi Intrinsik, Sikap dan Norma Subjektif berpengaruh terhadap Niat Berwirausaha.

\section{DAFTAR PUSTAKA}

Anis, E., Shocrul, R., Ahmad, R., S., Alfian, R., \& Desynta, R., G. (2020). The role of motivation on attitudes and entrepreneur achievement. Systematic Review in Pharmacy, 11(8), 335-343.

Anwar, H. (2009). Penilaian Sikap Ilmiah dalam Pembelajaran Sains. Jurnal Pelangi Ilmu, 2 (5), 103-112.

Chatterjee, N., Das, N., \& Srivastava, N. K. (2019). A structural model assessing key factors affecting women's entrepreneurial success: Evidence from India. Journal of Entrepreneurship in Emerging Economies, 11(1), 122-151. https://doi.org/10.1108/JEEE$\underline{08-2016-0030}$

Deci, E. L., \& Ryan, R. M. (2010). Intrinsic motivation. The Corsini Encyclopedia of Psychology. doi: $10.1002 / 9780470479216$

Eagly, A. H., \& Chaiken, S. (1993). The psychology of attitudes. Harcourt Brace Jovanovich College Publishers.

Feldman, R.S. (1995). Social Psychology. New Jersey: Prentice Hall.

Hair, J. F., Ringle, C. M., \& Sarstedt, M. (2011). PLS-SEM: Indeed a silver bullet. Journal of Marketing Theory and Practice, 19(2), 139-152. https://doi.org/10.2753/MTP1069$\underline{6679190202 .}$

Hartono, J., \& Puspitowati, I. (2019). Pengaruh Attitude, subjective norms, dan self efficacy terhadap intensi berwirausaha pada mahasiswa fakultas ekonomiuniversitas tarumanagara. Jurnal Manajerial Dan Kewirausahaan, 1(2). 234-241.

Hansfel, L ., \& Puspitowati, I. (2020). Pengaruh attitude, subjective norm dan perceived behavior control terhadap entrepreneurial intention. Jurnal Ekonomi dan Bisnis Indonesia, 2(4). 985993.

Kementerian Perindustrian Republik Indonesia (Kemenpri). (2018). Indonesia butuh 4 juta wirausaha baru untuk menjadi negara maju. Jakarta: Kementerian Perindustrian Republik Indonesia (Kemenpri).

Lin, H. F. (2007). Effect of extrinsic motivation and intrinsic motivation on employee knowledge sharing intentions. Journal of Information Science, 33(2). 135-149.doi: 10.1177/0165551506068174.

Listyawati, I. H. (2020). Pengaruh pendidikan kewirausahaan dan motivasi terhadap niat berwirausaha. Jurnal Bisnis, Manajemen, dan Akuntansi, 7(2), 110-118.

Munawar, A., \& Supriatna, N. 2018. Pengaruh Sikap dan Motrivasi Terhadap Minat Berwirausaha Siswa. Jurnal Kajian Pendidikan Ekonomi dan Ilmu Ekonomi, 2(1).

Nur, S., R., \& Amir., H. (2017) Pengaruh Efikasi Diri, Norma Subjektif, Sikap Berperilaku dan Pendidikan Kewirausahaan terhadap Intensi Berwirausaha. Jurnal Inspirasi Bisnis dan Manajemen, 1(7), 63-74,http://dx.doi.org/10.33603/jimb.v1i1.481.

Rahmawati, T., \& Mawardi, M. K. (2017). Pengaruh faktor perilaku dan faktor kontekstual terhadap niat berwirausa. Jurnal Administrasi Bisnis (JAB), 50(4). 115-121.

Rochayati, U., Kusumawardani, M. S., \& Sari, A. K. (2013). Pengaruh faktor sosiodemografi, 
sikap, dan kontekstual terhadap niat berwirausaha. Jurnal Kependidikan Penelitian Inovasi Pembelajaran, 43(2), 154-163. https://doi.org/10.21831/jk.v43i2.1970

Roscoe, J. T. (1975). Fundamental research statistics for the behavioural sciences (2nd Edition). In Holt Rinehart \& Winston, New York.

Schwarz, N., \& Bohner, G. (2001). The construction of Attitudes, Blackwell Handbook of Social Psychology, Interpersonal Processes, pp, 436-457. New York and Oxford: Blackwell

Sugiyono. (2008). Metodologi penelitian Kuantitatif, Kualitatif, dan R\& D. Bandung: Alfabeta.

Soomro, B. A., \& Shah, N. (2015). Developing attitudes and intentions among potential entrepreneurs. Journal of Enterprise Information Management, 28(2), 304-322.doi: 10.1108JEIM-07-2014-007 